Arh. hig. rada toksikol., 30 (1979) suppl. pp. 1725-1734.

\title{
OCCUPATIONAL HEALTH PROBLEMS IN OHF-SHORE OIL OPERATIONS IN IRAN
}

\author{
J. ARYANPUR \\ Public Health and Occupational Medical Services, National Iranian Oil Company, \\ Tebran, Iran
}

\begin{abstract}
The purpose of this paper is to review the results of a preliminary survey conducted by our occupational health team regarding the main occupational health problems affiliated with the National Iranian Oil Company and other off-shore oil companies in the Persian Gulf, which began operating in 1958. The report is based upon the results obtained from qucstionnaires, direct communication with the authorities conccrned, site visits and evaluation of some environmental factors.

Environmental heat forms one of the major occupational health problems in this area. The average temperature in the shade in summer is about $40{ }^{\circ} \mathrm{C}$, with humidity spells as high as $100 \%$. In spite of such adverse climatic conditions no instances of clinical hcat cxhaustion arc recorded, due to optimal air-conditioning of the living and recreational quarters, where the employees spend most of their time in hot seasons. The use of light clothing, protection from sunlight exposure (helmets, working in shade), consumption of adequate amount of salt and fluid are additional protective factors. Operational heat loss is increased by the outdoor nature of the operations. Occupational noise is another major problem. Diving operations take place in depths of 30 to 80 meters. A mixture of oxygen and helium is used instead of compressed air in depths greater than 50 meters. Diving accidents have occurred less often than during similar opcrations in rough seas with cold waters.

Other occupational health problems are reviewed and the difficulties of tackling them are discussed. Suggestions are made for a better control of occupational health problems of these companies.
\end{abstract}

The off-shore oil industry is a rclativcly new industry. It was started in the Gulf of Mexico in 1932, and in Iran it was introduced in 1958.

Data about the health hazards in this new industry are very scarce. The Scottish Council Report of 1974 on the Medical Implications of the Oil Related Industry 5 threw some light on the subject and drew the attention of interested authorities to the potential dangers and hazards of such operations in a hostile environment.

In order to investigate the health problems and hazards among the employees of the Persian Gulf off-shore oil companies affiliated with the National Iranian Oil Company (N.I.O.C.) a preliminary survey was carried out 
by the occupational health team of the N.I.O.C. between August 1977 and August 1978. The present report is based upon the results of the survey obtained from questionnaires, direct communication with the authorities concerned, site visits, and evaluation of some of the environmental factors.

Since many of the health problems in off-shore oil operations are similar to those on-shore, this paper will point out the differences and concentrate on problems which are more or less specific to off-shore oil operations in the Persian Gulf area.

Similar to many other off-shore oil projects, the following operations are usually assigned to different contractors specializing in exploration, drilling, laying of underwater pipelines, construction and installation of platforms and jetties, etc. Production and living platforms etc. are constructed un the mainland or abroad and then transported in parts to the site to be assembled and erected on the spot.

Once production starts, all activities are carried out by the employees of the companies involved. Air transpurt and stand-by helicoptcr scrvicc arc provided by different airlines and helicopter companies. Marine operations, major overhauls, sandblasting, painting, diving, food preparation, laundering, housekeeping, etc. are the responsibility of the contractors.

\section{THE WORK FORCE, WORKING AND LIVING CONDITIONS}

The work force employed in the off-shore operations of these companies can be roughly divided into four categories:

1. Fxploration and drilling crews. These work and live on mobile drilling rigs and are either forcign or Iranian nationals employed by the contractors.

2. Construction crews. These are foreign or Iranian employees of different companies who work on pipeline lay barges, crane barges, etc.

3. Production platform crews. Once the production platforms are crected they are manned by permanent Iranian employees of the off-shore oil companies.

4. Transportation and catcring crews. These include the crews of the supply boats, and employees in the catering and housekeeping services which are run by different companies and contractors.

Since the size of the work force supplied by various companies and contractors changes considerably from time to time, only the number of employees currently involved in production could be established.

The total number of the employees of these companics is $3360 ; 1030$ of these work in the central offices in l'ehran, while 1775 work at the mainland (BOC) or island installations (in Kharg, Lavan and Sirri) and 555 on off-shore platforms. The employees of different contractors and some 550 men of the drilling crews working at present for these companies are not included here.

While the employees of the central offices in Tehran work normal office hours, the remaining 2330 work on "satellite basis", i.e. 7 or 14 days on (the 
mainland or island) bases or platforms followed by 7 days of rest at their home towns. On platforms or base (mainland or island) installations, shift employees are 12 hours on duty followed by 12 hours of rest, with a weekly rotation of day and night shifts.

On many platforms some employees have their own private bedrooms, but the majority share their bedrooms with others. Somo bedrooms aIe provided with private toilets and showers, while in some cases there is only one toilet and shower for every 2 to 4 rooms. All offices, control rooms, mess roums, recreation halls and bedrooms are fully air-conditioned.

Breakfast and 2 hot meals are served to the cmployees besides coffee or tea and soft drinks during breaks. On the platforms, water is obtained by desalination or, on occasions, supplied from the mainland by tankers. Bottled mineral water for drinking is available to all employees on the platforms.

Movies are shown practically every night. Television, radio, music and other recreational facilities such as table tennis, billiards, etc. are available in the mess rooms.

The off-shore installations of these companies are located in a subtropical zone where the hot and humid climate necessitates air-conditioning (cooling and dehumidification) at least for 6 to 7 months in the year. Average temperature in the summer is about $35{ }^{\circ} \mathrm{C}$ (in the shade), maximum temperature reaching 42 to $44{ }^{\circ} \mathrm{C}$ (in the shade). Average relative humidity is $75 \%$ with maximum spells of $100 \%$ in summer nights. Average winter temperature is around 13 to $15{ }^{\circ} \mathrm{C}$. Winters are short and the temperature never reaches zero. Average wind vclocity is 15 knots $(36.5 \mathrm{~km} / \mathrm{hr})$ with a maximum of 45 knots $(110 \mathrm{~km} / \mathrm{hr})$. Wave height reaches $3 \mathrm{~m}$ in winter. There are occasional dust storms in the summer. The results of some of the measurements of heat (dry and wet bulb temperatures) made during our visits are shown in Table 1.

About $50 \%$ of the employees working on platforms or at mainland or island installations live in Tehran, $35 \%$ live in Abadan and the rest live in other cities. Employees commute from their home towns to the mainland or island bases by regular charter flights, with an average flying time of $1 / 2$ to 2 hours. Those working on the platforms travel by helicopters, with an average flying time of $1 / 4$ to 1 hour. Under certain conditions, employees have to travel to the platforms by boat. Stand-by helicopters are always ready for routine or emergency flights.

Doctors and dressers employed by the companies are stationed in clinics at the mainland or island bases. A first-aider is stationed on each of the living platforms at all times. Emergencies on the platforms are sent to the doctors at the bases, but when necessary, doctors visit emergency patients on the site. Those requiring hospitalization are transferred by helicopter or airplane to the nearest hospital or to one of the better equipped hospitals in Abadan, Tehran or Shiraz.

All employees working on platforms have to undergo medical screening in order that their fitness for work under the demanding conditions be established. I'he work force at the bases and on platforms consists exclusively of male workers of 20 to 45 years of age (average 30 years). About $50 \%$ of them are married. Each company has a safety officer. 
TABLE 1

Results of tempcraturc measurements with whirling hygrometer (June-July, 12 a.m. -3 p.m.).

\begin{tabular}{|c|c|c|c|c|}
\hline \multirow{2}{*}{ Platform } & \multirow{2}{*}{ Site } & \multicolumn{2}{|c|}{ Temperaturc $\left({ }^{\circ} \mathrm{C}\right)$} & \multirow{2}{*}{$\begin{array}{c}\text { Relative } \\
\text { humidity\%* }\end{array}$} \\
\hline & & Dry bulb & Wet Bulb & \\
\hline Living (N) & $\begin{array}{l}\text { Mess hall } \\
\text { Bedroum } \\
\text { Open air (shade) }\end{array}$ & $\begin{array}{l}25.0 \\
25.0 \\
31.1\end{array}$ & $\begin{array}{l}19.4 \\
19.4 \\
26.1\end{array}$ & $\begin{array}{l}60 \\
60 \\
68\end{array}$ \\
\hline Production (N) & $\begin{array}{l}\text { Control room } \\
\text { Middle desk (shade) } \\
\text { Near generator (outdoors, shade) } \\
\text { W/shop (outdoors) } \\
\text { Lower deck (outdoors, shade) }\end{array}$ & $\begin{array}{l}25.0 \\
31.7 \\
32.8 \\
31.7 \\
31.7\end{array}$ & $\begin{array}{l}18.3 \\
26.7 \\
27.8 \\
26.7 \\
26.7\end{array}$ & $\begin{array}{l}53 \\
68 \\
68 \\
68 \\
68\end{array}$ \\
\hline Living (B) & $\begin{array}{l}\text { Office } \\
\text { Mess hall } \\
\text { Bedroom }\end{array}$ & $\begin{array}{l}25.0 \\
25.0 \\
22.0\end{array}$ & $\begin{array}{l}20.0 \\
20.0 \\
17.2\end{array}$ & $\begin{array}{l}63 \\
63 \\
61\end{array}$ \\
\hline Production (B) & $\begin{array}{l}\text { Control room } \\
\text { Lower deck (shade) }\end{array}$ & $\begin{array}{l}26.7 \\
31.7\end{array}$ & $\begin{array}{l}21.1 \\
26.7\end{array}$ & $\begin{array}{l}61 \\
68\end{array}$ \\
\hline Drilling (B) & $\begin{array}{l}\text { Control room } \\
\text { Upper deck (sunshine) }\end{array}$ & $\begin{array}{l}27.8 \\
32.2\end{array}$ & $\begin{array}{l}22.2 \\
27.2\end{array}$ & $\begin{array}{l}62 \\
68\end{array}$ \\
\hline Living (F) & $\begin{array}{l}\text { Mess hall } \\
\text { Bedroom }\end{array}$ & $\begin{array}{l}25.6 \\
25.6\end{array}$ & $\begin{array}{l}20.6 \\
20.6\end{array}$ & $\begin{array}{l}64 \\
64\end{array}$ \\
\hline Production (F) & $\begin{array}{l}\text { Control room } \\
\text { Open air (shade) } \\
\text { Between generators }\end{array}$ & $\begin{array}{l}21.1 \\
33.3 \\
38.9\end{array}$ & $\begin{array}{l}15.6 \\
28.3\end{array}$ & $\begin{array}{l}56 \\
69\end{array}$ \\
\hline Living $(\mathrm{R})$ & $\begin{array}{l}\text { Mess hall } \\
\text { Bedroom }\end{array}$ & $\begin{array}{l}23.9 \\
23.9\end{array}$ & $\begin{array}{l}18.3 \\
18.3\end{array}$ & $\begin{array}{l}59 \\
59\end{array}$ \\
\hline Production (R) & $\begin{array}{l}\text { Control room } \\
\text { Open air (shade) } \\
\text { Between gencrators }\end{array}$ & $\begin{array}{l}24.4 \\
35.0 \\
37.2\end{array}$ & $\begin{array}{l}17.8 \\
30.0\end{array}$ & $\begin{array}{l}52 \\
69\end{array}$ \\
\hline Living (A) & $\begin{array}{l}\text { Recreation hall } \\
\text { Office } \\
\text { Corridors } \\
\text { Bedroom }\end{array}$ & $\begin{array}{l}23.3 \\
23.9 \\
23.9 \\
22.2\end{array}$ & $\begin{array}{l}16.7 \\
16.7 \\
17.2 \\
16.7\end{array}$ & $\begin{array}{l}51 \\
48 \\
51 \\
57\end{array}$ \\
\hline Production (A) & $\begin{array}{l}\text { Control room } \\
\text { W/shop (outdoors) } \\
\text { Between generators }\end{array}$ & $\begin{array}{l}23.3 \\
33.3 \\
35.0\end{array}$ & $\begin{array}{l}17.8 \\
28.3\end{array}$ & $\begin{array}{l}58 \\
69\end{array}$ \\
\hline $\operatorname{Rig}(\mathrm{A})$ & Well manifold (shade) & 33.3 & & \\
\hline
\end{tabular}

* Relative humiditics corresponding to the different dry-bulb temperatures are derived from the table of relative humidity $y^{6}$, by assessing the wet-bulb depression ( $=$ dry-bulb temperature minus wet-bulb temperature).

Communication between the platforms and the mainland or island bases is by radio and microwave (two ways telephones). The work force on the platforms of the off-shore oil companies generally consists of young, physically healthy men who have chosen to work in such locations mainly because of the higher financial rewards. In spite of this the rate of turnover in the first and second years 
of employment, particularly among the unmarried, is high (about $50 \%$ ). This is considered to be mainly due to the nature of their work and separation from their families.

\section{PROBLEMS ASSOCIATED WITH SATELLITE OPERATION AND REMOTENESS}

The major problem for most employees working at off-shore installations are the nature of their work, which can have adverse effects on their health and well-being. The most prevalent symptoms among off-shore workers particularly those working for longer periods, are boredom, insomnia, feeling of indifference, tendency towards isolation, depression, irritability and dyspepsia.

The factors that may contribute to these states includc the workers' separation from their families, friends and society, lack of adequate communication with the outside world, obligatory living at the working premises, lack of privacy, comparatively inadequate recreational facilities, living at sea with a limited possibility of leaving the premises, difficulties of transfer to other sites, long hours of work, long hours of travelling and flight, long waiting hours at airports and bases, etc.

\section{Heat}

Environmental heat forms one of the major occupational health problems in this area. As mentioned before, the wcather in this area is extremely hot and humid. Hot weather necessitating air-conditioning (cooling and dehumidification) starts in April and continues through Octobcr. During these months the climatic conditions prevailing in the area and on platforms are well in excess of the comfort range 3 and can be more or less compared to those on commercial ships and tankers sailing the warm seas ${ }^{2}$ with the difference that on the platforms all machinery is placed outdoors.

In hot seasons, only a few cmployees on the platforms stay mostly indoors in air-conditioned premises (bedrooms, restaurants, control rooms, offices, etc.), while others have to go out more often and stay therc for longer periods. For instance, operators who form about one half of the work force, have to go out about once an hour and stay there from 10 to 30 minutes. Thereforc the total duration of their exposure to heat, during a 12 hour shift is about $2-3$ hours. Operators and maintenance crew may have to do up to $8-9$ hours of work in places without air-conditioning during a 10 hour shift. However, during meal hours or tea breaks and whenever they feel tired or hot they can spend their time in air-conditioned places. The work they perform may be classified as light to medium.

Despite these adverse climatic conditions luring the hot seasons, fortunately no serious cases of heat exhaustion have been encountered among the employees up to now. Medical records and interviews with the medical officcrs concerned showed only a few (3) cases of heat effect due to long hours of exposure to sunshine without adequate protection. The cases had responded well to cooling and oral fluid therapy. Few cases of sunburn have been noticed 
particularly among the contractors" European persumel who tend to worls outdoors without their shirts on.

The factors which are thought to contribute to this relative protection of workers against environmental and operational heat are as follows:

- Spending as much time as possible in air-conditioned quarters cluring the hot season;

- Consuming adequate amounts of fluids and salt (in the form of salt lablets or additional salt with meals);

- Wearing light cotton clothing;

- Reducing the direct exposure to sunshine to a minimum by the use of helmets, shades etc. Most of the middle and lower decks arc not exposed to direct sunshine;

- Working during the cooler hours of the day, particularly when the work is to be carried out in closed spaces;

- Operations requiring the use of special protective clothing (e.g. sandblasting etc.) are performed during the cooler hours and with more frequent intervals of rest in between;

- Using blowers in closed or partially closed spaces improves the ventilation and cools the air inside the containers;

- Reducing the exposure time to heat, with intervals of rest in air-conditioned places;

- The fact that all machinery is located in the open ensures a better dissipation of operational heat;

- The workers are young and healthy men and have at least one shower a day;

- A certain degree of acclimatization of the workers to environmcntal heat; Spending the rest days in a better climate, after one or two weeks of work in a hot environment.

Noise

Another major problem is occupational noise which is discussed in a separate paper ${ }^{4}$.

\section{Diving}

Diving for exploration, drilling, laying underwater pipelines, constructing platforms of jetties, and doing major maintenance work is carried out by special contractor groups employing expert divers. Diving operations for routine inspection, cleaning and minor maintenance work, which are usually carricd out in shallow waters and for brief periods not exceeding 30 minutes, are performed by divers employed by the off-shorc oil companies. Diving operations take place in depths of 15 to 80 meters. In depths exceeding 50 meters, instead of compressed air a mixture of oxygen and helium is used. Divers use scuba, masks and fins, compressed-air cylinders, knives, shark guns and the usual diving tools. When necessary, divers working at greater depths use helmets and communicate by radio. 
The need for deep-diving operations is much less frequent in the Persian Gulf than in the North Sea, and therefore diving operations in the Gulf take place only in day time and when the sea is calm and clear. The sea water is never cold, and until now sharks and sea snakes in these parts of the Persian Gulf have not created any problems for the divers. A rcvicw of diviny incidents showed 2 fatal accidents and two cases of bend and shortness of breath which had recovered after being treated in the decompression chambcr.

It nilust be mentioned here that diving for off-shore petroleum operations is known to be one of the most dangerous occupations. According to the Scottish Council Report, the annual fatality rate for deep sea divers is approximately 10 per 1000 employed, which is 8 times higher than that for ncar and midale waters trawlermen, 33 times that for coal miners, 50 times that for construction workers, and 220 times that for factory workers 1 . A comparison of the fatality rates of diving operations in the North Sea with those of diving operations in the Persian Gulf underlines the hostile nature of the North Sea and the inherent hazards of diving operations in that sea 6 .

\section{Chemical hazards}

Gassing by hydrogen sulphide forms one of the potential health hazards for personnel working on platforms handling sour petrolcum crudes. A few instances of gassing on the platforms have been reported, all but one of which were successfully resuscitated.

It appears that on off-shore platforms exposure to hydrocarbons and benzene in petroleum is less than in similar operations on land. This is because the platform floors are metal and thus allow a more thorough cleaning and washing. Also the outdoor nature of the operations prevents an accumulation of gases.

When opening chemical containers or handling, pouring, mixing or carrying these materials, workers may get cxposed to the chemicals used on the platforms. These consist of dietanolamine (DEA), sulphuric acid, hydrochloric acid and the ingredients of various proprietary brands used as corrosion inhibitors, antifoam and de-emulsifiers, etc.

Sandblasting is an operation carried out by contractors prior to painting the rig installations and platforms. Workers performing this operation are exposed to sunshine and environmental heat in addition to silica dust.

Most of the painting of the platforms and industrial installations is done by the contractors. No lead paint is used on thcse premises. Paints sprayed on top or dcck structures consist of zinc silicate or inorganic zinc as primer, and layers of chlorinated rubber. Splash zones are sprayed with layers of epoxy coal tar paints. No spray painting work is carried out during high humidity spells.

The danger of serious accidents during the various off-shore operations is great and thercfore strict observance of safety and work instructions is required. Out of a total of 13 fatal accidents since the start of the off-shore operations, 10 occurred among the contracturs' personnel. The hazards of fire and explosion are 
similar to those at petroleum installations on the mainland with the difference that fire fighting, rescue and first aid services from outside are limited and usually arrive after a certain delay.

Some chronic conditions such as asthma, mental disorders, skin diseases etc., are likcly to recur under these climatic and working conditions.

The hot and humid condition prevailing on the platforms in this area are considered to be a predisposing factor for the growth and development of mycotic skin infections. According to records and the statements of doctors and dressers of the companies mycotic affcctions of the armpits and groins, athlete feet and pityriasis versicolor are more prevalent among platform personnel than among others. The possibility of contamination of clothing in the laundry and infestation of the feet from the bathroom floors should be considered.

Most of the doctors working at the bases noted a disproportionatc number of cases of renal colic and urolithiasis. This observation warrants further studies.

\section{DISCUSSION AND CONCLUSIONS}

The size, number, geographical distribution and remoteness of off-shore oil installations and the involvement of different contractors at the individual stages of operation, tend to hamper such studies and on optimal provision of somc of the health and safety requirements by the respective companies.

Curative facilities such as a permanent doctor, dressers and training of first-aiders together with hospital back up, offer a relatively good health service to all employees; nevertheless, occupational medical and industrial hygicnic requirements are more or less neglected. It is believed that doctors working in these areas can do a great deal in this respect if thcy are given training on the principles of occupational health and information on the health problems and hazards involved in off-shore oil opcrations, particularly in this area. This can be done by organizing short courses at suitable academic institutions and visits to occupational hcalth centers such as those of the N.I.O.C. In addition to this the occupational health team of the N.I.O.C. can offer this servicc on a consultative basis.

It must be emphasized here that pre-employment health screening is of great importance for off-shore workers since they work and live for long periods in remote areas and thus must have high standards of physical and mental fitness.

Off-shore personnel have also a greater need for special first-aid, rescue and safety training. This must be ensured despite a high rate of turnovcr.

Lack of an adequate and uniform system of recording, reporting and analysing accidents is another difficulty. Although each company keeps records of disabling and fatal accidents for insurance, compensation or legal purposes, data on the frequency and severity degrees of accidents among workers at off-shore installations were not available in most instances. Data about accidents among the contractors personnel are practically limited to those received indirectly from company doctors attending the more serious or fatal cases, or 
from transportation services transferring these to the nearest hospitals. It is felt that safety on the premises of the companies and their contractors should be strengthened and a better liason and exchange of information established between the safety officcrs of these companies and the N.I.O.C. All accidents should be recorded and reported, and copies of the safety reports of the companies and their contractors sent to the N.I.O.C.

A review of the fatal accidents compiled by the survey team shows that accidents mainly occur among the personnel of contractor companies who perform the most dangerous and hazardous jobs. Out of 13 fatal accidents studied, 10 had occurred among employees of the contractors.

This preliminary survey shows that the problem of cnvironmental heat and humidity on the platforms is well under control, as despite the adverse climatic conditions no instances of serious heat effect were observed among the employces. This is mainly due to the efficient air-conditioning of the living quarters and some of the working premises, and partly to a strict observation of certain health and safety instructions and regulations regarding measures of precaution.

Diving hazards which elsewhere constitute a major problem and the cause of most fatal accidents are fortunately far less present in this region owing to the favourable local marine conditions and the naturc of the operations.

T'he most important problem of those working on off-shore oil platforms can be related to the remoteness of the installations and the specific nature of the working schedules. Continuation of this style of work over longer periods can undoubtedly result in familial problems and in behavioural or mental disorders. It is fclt that a balanced interchange of the work and rest periods, i.e. 7 days of work on the platform versus 7 days of rest at the home hase, many of the problems of work on the platforms could be climinated. At present such schedules are practiced only in the case of a very few responsible positions and on a seniority basis (after 10 years of service).

With the provision of optimum working and living conditions on off-shore oil platforms, work in these places will bring the workers not only a higher income, but also greater satisfaction with work and life, resulting in beneficial effects on their health, well-being and working efficiency.

\section{REFERENCES}

1. Anonimons. Hazards of the oil industry. Br. Med. J., 3 (1975) 556.

2. Bedford, T. Environmental Warmth and its Measurement, London, Her Majesty's Stationery Office, 1957.

3. Crockford, G.W. The Thermal Environment, Occupational Health Practice, Butlerworths, London 1973, pp. 313-314.

4. Eskandary, C., Aryanpour, J. and Faranjpour, F. Noise in off-shore operations. In: Pleština, R. ed. Physical Hazards, Dusts and Vapours, Occupational Hygiene. Proceedings of the 19th International Congress on Occupational Hcalth, Dubrovnik 1978. Arh. Hig. Rada Tuksikol., 30 (1979) suppl. $745-751$. 
5. Scottish Council Report. The Medical Implications of Oil Related Industry, Edinburgh, British Medical Association, 1975, pp. 4-5.

6. Scottish Council of the British Medical Association. Medical aspects of North Sea oil. Br. Med. J., 3 (1975) $576-580$. 